\title{
Opinion Polarisation in Indonesia Politics
}

\author{
Senja Yustitia ${ }^{1}$, Muhammad Edy Susilo², Subhan Afifi ${ }^{3}$ \\ \{senja.yustitia@upnyk.ac.id ${ }^{1}$, muh_edy_susilo@yahoo.co.id² ${ }^{2}$ subhanafifi@gmail.com³ ${ }^{3}$, \\ ${ }^{1,2,3}$ Department of Communication Science Universitas Pembangunan Nasional "Veteran" \\ Yogyakarta, Indonesia
}

\begin{abstract}
Since the Indonesian presidential election in 2014, there are two emerging phenomena that are polarizing political opinions and spreading hoax. Polarisation of opinion causing the public divided into two major groups, the pro and contra - groups toward government. The polarisation is felt even after the presidential election was over and it metamorphosed when Jakarta Province governor election held in 2017. This research tries to analyze how each pro and contra - side in seeing the phenomenon of hoax and how their attitudes and opinions towards opposing groups. The research method used is qualitative descriptive by conducting focus group discussion, in-depth interview and observation. The criteria of informants are social media activists who are pro and contra to the government, the government represented by Ministry of Communication and Information Technology and social media observers. The technique of collecting data use FGD and interview. The research results show that each group has a high level of judgment against other groups including in assessing the phenomenon of hoax. It causes the difficulty on creating constructive discussions because the pro and contra only speak in their sphere and community. The government has made a series of efforts to solve polarisation and hoax by forming the Nusantara Taskforce, doing literacy through Ministry of Communication and Information Technology and legal action for the people who are involved in. But so far, the efforts have not shown a positive result.
\end{abstract}

Keywords: Hoax, Polarisation, Attitude, Opinion.

\section{Introduction}

Presidential Election in 2014 is Indonesia's 4th election after the reformation. When the New Order, election talks rolled on the lack of freedom of the community in determining the choice due to government intervention. The 2014 Election which grew up in the era of freedom of opinion was marked by a new phenomenon namely the fertile hoax that attacks each partner. According to Emery in Rumors article, urban legends and Internet Hoaxes, hoax is an act, document or artifact intended to deceive the public [1]. From the definition, it is seen that hoaxes have the purpose of deceiving the broad audiences.

In various writings and research results, hoax is also called as a fake news. Hoax in the 2014 election attacked each of the president and vice president candidates namely Joko Widodo - Jusuf Kalla and Prabowo Subianto - Hatta Rajasa. Joko Widodo side in various hoax news mentioned as a figure who is not Muslim (and even has a Christian baptism name) and PKI henchmen. While Prabowo is always associated with the actor of human right violator. 
Not only that, hoax also attacked the Central Election Commission for example the ballot for the overseas election area of Hong Kong which contains only one picture of candidate pairs only.

The 2014 election ended with the result of candidate pair of Joko Widodo-Jusuf Kalla winning (53.15\%) defeating Prabowo Subianto - Hatta Rajasa (46.85\%) [2]. The ending of the 2014 presidential election did not stop the contestation. If during the election competition occurs between candidate pairs, after election, polarisation between supporters are still occured. Jokowi is regarded as anti-Islamic president while Prabowo is on the opposite, as well as his supporters. The circulating hoax also revolves around the polarisation even sentiments towards Jokowi are no longer private but also represent government entities. Whether or not it is realized, the government is the target of hoax produced by social media. Some hoaxes addressed to Joko Widodo as well as the government are the arrival of 10 thousand workers from China, Jokowi as PKI stooge and adzan ban by using loudspeakers and others.

Polarisation and hoax became a continuing phenomenon in the election of DKI Jakarta in 2017. The emergence of two pairs in the final round of election namely candidate pair of Anies Baswedan - Sandiaga Uno and Basuki Tjahaja Purnama (Ahok) - Djarot Saiful Hidayat. Sentiment against both is the same. Anies - Sandiaga is called to represent the Islamic group while Ahok-Djarot is on the opposite. Hoax is targeting Anies for example Jakarta Syariah will be applied if Anies was elected as Governor of DKI. Conversely, if he failed, there will be the Islamic Revolution [3]. Also appeared a hoax about a grandmother, Hindun, whose body abandoned by citizens for choosing Ahok in the first round election. Still, the spread of hoak spreaded through social media and conversation applications like WhatsApp and telegram made the second successful team of candidate pair determined to fight it because in addition to affecting voters also resulted in electability decrease [4]. Hoax is a troubling matter. CoFounder of "Hidupkan Kembali Hoax", Khairul Ashar, said there were 1,900 reports of alleged false news in the last three months ahead of voting for the Jakarta election. Of these 1000 reports have been confirmed as hoax [5]. After the 2017 election of DKI, there is still a hoax tendency to be produced both related to the leadership of Anies - Sandiaga and other election in Indonesia.

In general, the massive hoax or fake news has a very serious impact. In a study entitled "Fake News Detection on Social Media: A Data Mining Perspective" fake news not only affect to the individual level but also the community. First, fake news can break the authenticity balance of the news ecosystem. In the paper mentioned that in the case of the US presidential election in 2016, fake news that spread widely through Facebook more popular than the news circulating in the mainstream media. Second, fake news intentionally persuades consumers to accept biased or false beliefs. Fake News is usually manipulated by propagandists to convey political messages or influence. Third, fake news changes the way people interpret and respond the real news [6].

At the case level in Indonesia, fake news is correlated with low public confidence. This distrust occurs on the party to which the hoax is targeted and also the distrust of the actual news or reality. The growth of fake news makes it difficult for audiences to recognize between objective and false reality. This plot is all certainly on the disintegration of the nation. In a hoax targeting the government, the public and the government are busy commenting on the hoax that occur rather than criticizing policies from the essential side. That is why, in many instances, people are caught in a debate that leads to divisions and not to the search for solutions together. Not only that, a healthy discussion was not awakened because from the beginning felt in a different group. 
Another problem is that these two polarized camps are just busy in virtual space, such as social media and conversation applications, but it's just a quiet debate at meetings in the real world. Polarisation often warms with the development of certain issues. According to the government, there are three main issues that attack the government related hoax namely antiIslam, pro-communist and pro-China [7].

It is against this background that this research tries to unravel how each side (pro and cons) in looking at the phenomenon of hoax and how their attitudes and opinions towards opposing groups.

The theory used in this research is the theory of cognitive dissonance. The theory of cognitive dissonance is a theory in social psychology that addresses the feelings of one's discomfort due to conflicting attitudes, thoughts, and behaviors and motivates one to take steps to reduce the discomfort. The term of cognitive dissonance was first popularized by a psychologist named Leon Festinger in the 1950s.

The theory of cognitive dissonance has amount of assumptions or basic assumptions. Humans have a desire for consistency in their beliefs, attitudes, and behaviors. This theory emphasizes a model of the basic nature of human beings with an emphasis on stability and consistency. Cognitive dissonance arises when there is inconsistency because one is exposed to two different beliefs, or between belief and action [8]. Dissonance is created by biological inconsistency. This theory refers to the fact that a psychological inconsistency with other inconsistencies, causing cognitive dissonance.

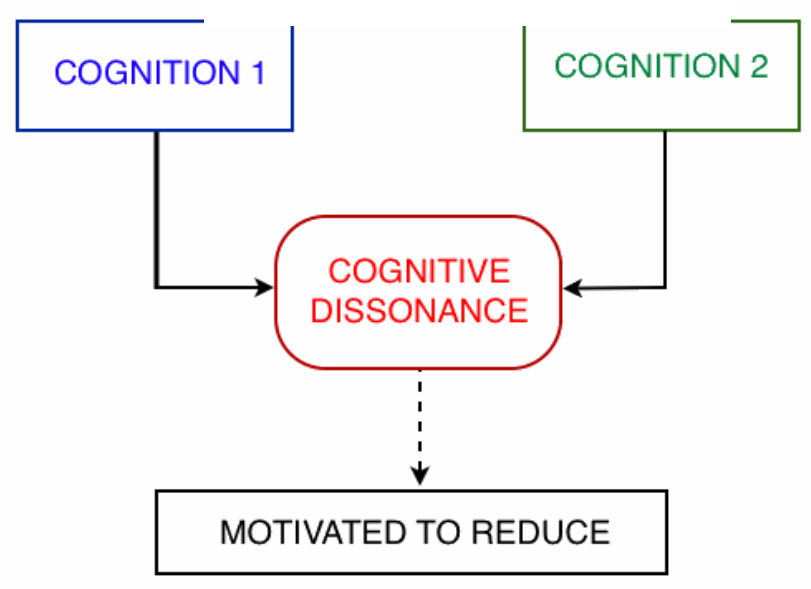

Fig 1. Cognitive Dissonance Chart [9] 


\section{Method}

The method used for this research is descriptive qualitative with focus group discussion technique, in-depth interview and observation. Focus group discussion (FGD) is a systematic process of gathering data and information about a very specific problem through group discussion [9]. FGD in this research involves audiences that are active in social media and have a pro, contra and neutral tendency towards government. FGD informants have diverse backgrounds ranging from students, Islamic activists, and lecturers both pro and contra with the government.

In addition to conducting FGD, the researchers also dig the opinions of informants through an indepth interview consisting of social media activists who are pro and contra to the government i.e. Ulin Yusron (government pro-side) and Jonru Ginting (government contraside). On the twitter account, Ulin (@ulinyusron) has follower 118 thousand and on instagram account (ulinyusron) followed by 13.4 thousand followers. While Jonru Ginting's Facebook page followed by 1.479.247 followers. Informants were chosen because they were in the polarisation and actively used their media social accounts to express their opinions.

The researcher also interviewed the Expert Staff of Kominfo Prof. Dr. Drs. Henri Subiakto, SH.M.Si as a representation of the government. Not only that, researchers also participated actively by following discussions related to hoax. First participated in the 'Ghost Hoax' Public Discussion organized by Jakarta Journalists' Poros (14/3/2018) with Wawan Hari Purwanto as resource person (Director of Communication and Information of BIN), Brig. Gen. M. Iqbal (Police Public Relations Division), Nukman Lutfie (social media observer), Rahadi T. Wiratama (senior researcher of LP3ES) and Budiarto Shambazy (senior journalist of Kompas).

Second, the Police Independence Discussion series in Democracy Party Festivals entitled"Between Freedom of Opinion, Hoax and Hate Speech" (21/3/2018) organized by the Indonesian Association of Teachers and Indonesian Police (ISPPI). The speakers who attended the discussion were Ismail Fahmi (Researcher and Technopreneur in the field of science and information), Mustofa Nahrawardaya (social media activist), Brig. Pol. Fadil Imran (Director of Criminal Cyber Bareskrim Mabes Polri), Prof. Dr. Drs. Henri Subiakto, SH. M.Si (Kominfo Expert Staff) and Nasir Djamil (member of DPR RI).

\section{Research Result and Discussion}

\subsection{Hoaxes and Goverment}

According to one pro-government activist, Ulin Yusron, hoax is something that does not have the fact of the event, no actions of people do something but reported otherwise. According to him, hoax material can be deeds, images, titles or issues that are deflected to be inconsistent with the facts. While for social media activist, Jonru Ginting hoax is the wrong news or in other words it is not true news.

In the FGD conducted to explore opinions about hoax in relation to the nation's integration, their opinion about hoax is almost similar. Informants in the FGD agreed that in the hoax there were at least misinformation, unclear sources, misappropriation of facts, and slander. The purpose of hoax can be diverse for example, to lead public opinion and misdirection of information. How to do it can be very diverse. Hoaxes are also believed to be done by someone who has a certain motivation both related to politics and economics.

Associated with who is often the target of hoax, the opinion of the research informants is divided into 2 major groups. In the pro informants with the government, they agree with what is said by the police that the government is the entity most often targeted hoax. According to 
news reported by CNN Indonesia, Criminal Director of Cyber Bareskrim Police Headquarters, Brig. Gen. Fadil Imran stated that the government is the party most often the victims of circulation of fake news or hoax in social media [10].

From the side of the countra-group with the government, they sometimes see that hoax are actually produced by the state. In practice, this can be done through the palace buzzer because it is impossible for the government to do it alone. This is reinforced by the proliferation of news sites that clearly spread the hoax but not processed by the law because it supports the government. This is what makes contra-group believe that the government is doing selective logging in the action of dealing with hoax.

For those who are pro with government hoax motives targeting the government are used to delegitimize public confidence to the ruling government. All issues produced are the issue that is the weak point of Jokowi's political opponent. The reason for the spread of hoax is that the lack of opposition can be covered and the public only focuses on the ugliness of the government.

Pro-government activist Ulin Yusron mentioned there are at least 4 issues used to weaken Jokowi namely Jokowi PKI, Jokowi pro-China, Jokowi anti-Islam and Jokowi pro-foreign. This issue is used to undermine public confidence in the government. The issue is used to attack the government, or Jokowi as a person. According to Ulin, Jokowi can not be attacked by using other issues that are easily verified. This is the impact of Jokowi government that is clean and free of NCC (Nepotism Collusion Corruption) so that there are parties trying to create instability.

In contrast, countra-government activists say that pro-hoax propagators against the government as being maintained by the state. Instead, they often spread the hoax by vilifying Islam and ulama. This has attracted widespread public concern. Because the law in Indonesia is not firmly crack down on anti-Islam group that is consequently many people who then act alone. In short, there is a high distrust of the legal mechanisms in Indonesia. In general, the polarisation of popular and pro-governmental activist opinions can be seen in the following table;

Table 1. Comparison of Opinions on Hoax

\begin{tabular}{|c|c|c|c|}
\hline No & Point & Pro-Jokowi & Contra-Jokowi \\
\hline 1 & Definition of Hoax & $\begin{array}{l}\text { Something that does not fit the } \\
\text { fact, defamation }\end{array}$ & Wrong news \\
\hline 2 & Target of Hoax & Government & $\begin{array}{l}\text { - Society } \\
\text { - Theologian } \\
\text { - Muslim people }\end{array}$ \\
\hline 3 & Actor producing Hoax & $\begin{array}{l}\text { - Contra / } \\
\text { Opposition/Government } \\
\text { - The losers in the } 2014 \text { election }\end{array}$ & $\begin{array}{l}\text { - In some cases, government also } \\
\text { creates hoax } \\
\text { - Institution maintained by the } \\
\text { state }\end{array}$ \\
\hline 4 & $\begin{array}{l}\text { The motive of hoax } \\
\text { maker }\end{array}$ & Hatred & Criticism toward government \\
\hline 5 & $\begin{array}{l}\text { The purpose of hoax } \\
\text { maker }\end{array}$ & Government delegitimation & $\begin{array}{l}\text { Legitimizing government's } \\
\text { program }\end{array}$ \\
\hline 6 & Issue of hoax & $\begin{array}{l}\text { - Government is pro - Chinese } \\
\text { - Jokowi is Christian } \\
\text { - Jokowi is pro-foreginer } \\
\text { - Jokowi is anti- Islam }\end{array}$ & $\begin{array}{l}\text { The Issues are used to benefit and } \\
\text { support government programs. } \\
\text { For example, Indonesia lacks of } \\
\text { rice, Indonesia needs import of } \\
\text { salt, }\end{array}$ \\
\hline
\end{tabular}




\begin{tabular}{clll}
\hline No & \multicolumn{1}{c}{ Point } & \multicolumn{1}{c}{ Pro-Jokowi } & \multicolumn{1}{c}{ Contra-Jokowi } \\
\hline 7 & The beneficiaries of & - Prabowo & Government \\
& hoax & - Anies Baswedan & \\
& & - Opposition & Society \\
& The victim of hoax & - Society & \\
& & - Government &
\end{tabular}

Source: The primary data of research, 2018

The table above shows that both pro and contra of the government have the same understanding of hoax. Hoax or fake news is always associated with wrong news and distortion of fact or reality. However, those have different opinions when inquired more about the hoax and its relation to the government. When the discussion of hoax is concerned with the objectives and issues that becomes the hoaxed things, the opinions of the informants are polarized into certain attitudes. The neutral definition of hoax no longer determines how they see government entities or Jokowi as the target of hoax.

The opinion of activists pro - government who mentioned that the targets of hoax so far are government and Jokowi, determines how they see the government position. Hoaxs are interpreted as the attempts to delegitimize government. Besides, when researchers interview informants who oppose the government, the issues that are exhumed to the government are none other than ordinary criticism. Jonru mentioned that he also criticized the government of Susilo Bambang Yudhoyono (SBY). This case shows that the article about Jokowi on the social page of his media is not something tendentious. It reinforces the different views of both groups in addressing the hoax targeting the government.

\section{Government Efforts in Dealing with Hoax}

The circulation of hoax since the 2014 election continues in the 2017 Jakarta elections forced government to pay more attention to the situation. Recorded a number of things have been done by the government to overcome the circulation of hoax especially that harms the government. The establishment of Satgas Nusantara and Badan Sandi and Siber Nasional (BSSN), The media literacy campaign by Kominfo up to assertive action against person considered to spread hoax by police under the command of Director of Criminal Crime of Criminal Investigation Police. The government also often conveyed to the mass media that they would seriously crack down on the individuals who produced hoaxs and distribute them. Through the Minister of Communications and Informatics Rudiantara, the government will do two steps in overcoming the usage of negative internet. First, do filtering, second, law enforcement. This filtering or filtration is used to handle the site of hoax, while for those who propagate hate speech will soon be pulled down [11].

For all the efforts undertaken by the government, this research informant which is divided into pro and contra - group of government also give a different assessment. Pro - activist Jokowi assess that the government is not significant enough. However, they give an appreciation to the law enforcement that has been done by the police. The police in this case is mentioned to have worked on the greatest priority and destructiveness. That is why Saracen and MCA become two groups of hoax spreaders captured by the police.

In contrast, the counter-government activists saw that the government under President Jokowi's command was very unfair in making arrests and prosecutions of hoax. The impression that arises precisely, the government is very anti-Islam, so the account, web news, and other social media conversations that actually slander Islam is not prosecuted. The government is also evaluated to be very selective. 
In addition to legal action, the government also often dialogue with social media activists. Recorded in 2017 several times, they are invited President Jokowi to the State Palace. For example on June 22, President Jokowi also invited 50 social media celebrities to the State Palace [12]. On August 24th the same agenda was conducted. Some of the social media activists present were Arief Muhammad, Chico Hakim and Nita Kartika Sari [13]. Previously, Jokowi also invited 30 celebrities of social media on February 2, 2016 to discuss various issues on the platform [14].

In relation with the government's breakthrough to invite various elements of society and social media activists to the State Palace, there are various opinions that arise. In the progovernment group, they see this case as the part of the government's concern for social media. On the other hand, anti-government groups view the effort as insignificant as invited only from pro-government groups. Even if it invites religious leaders, it only involves Muhammadiyah and NU which generally do not have too sharp friction with the government. Conversely, the counter is never invited to dialogue in a forum.

How is the fundamental difference between pro and contra activists see the government's efforts to deal with the spreading of hoax seen in the following table.

Table 2. Opinions Related to the Government's Treatment of the Hoax Distribution

\begin{tabular}{|c|c|c|c|}
\hline No & Subject & Pro - Government & Contra- Government \\
\hline 1 & The police movement & - Appreciate & - Tebang pilih \\
\hline 2 & $\begin{array}{l}\text { To the group that has } \\
\text { been cracked down }\end{array}$ & $\begin{array}{l}\text { - Support the police action } \\
\text { - Let the law prove them wrong } \\
\text { or right }\end{array}$ & $\begin{array}{l}\text { - The propagation groups of pro } \\
\text { - government hoax are not } \\
\text { prosecuted } \\
\text { - The groups that have been } \\
\text { arrested are not guilty }\end{array}$ \\
\hline 3 & $\begin{array}{l}\text { The consolidation of } \\
\text { government with social } \\
\text { media activits }\end{array}$ & $\begin{array}{l}\text { Showing that Jokowi has great } \\
\text { concern for social media activits }\end{array}$ & $\begin{array}{l}\text { There will be no big impact if the } \\
\text { only invited group is pro - } \\
\text { jokowi or government }\end{array}$ \\
\hline 4 & $\begin{array}{l}\text { The solution toward } \\
\text { hoax distribution }\end{array}$ & $\begin{array}{l}\text { - Strengthening Cyber Security } \\
\text { - Working together with social } \\
\text { media providers and conversation } \\
\text { apps to verify social media users } \\
\text { - Anonymous accounts are not } \\
\text { allowed }\end{array}$ & $\begin{array}{l}\text { - Government should unite } \\
\text { citizen } \\
\text { - Government must be fair and } \\
\text { objective }\end{array}$ \\
\hline
\end{tabular}

Source: The primary data of research, 2018

Based on the table above, it is clear that the opinions of each party to the government's treatment of hoax so far have an effect on their opinions in regard to what the solution should be done. In the pro-group, the government is not the point of error, so the solution does not put the government in the central position. Cyber security can only be ecxecuted if the government cooperates with other parties related to data and network security systems including social media service providers. This case is certainly not merely the role of government, because in the case of leaked Facebook user data in US Election between Trump and Hillary, the weak point is not on the government but on the use of illegal data.

In contrast to counter-groups, they place the government as a central entity that plays an important role to solve this problem. Government is required to act fairly and objectively including to have an effort in uniting the split society in polarisation. The treatment of selective hoax case, not providing a dialogue room with opposing groups, is considered to widen the polarisation gap between the two groups. The role of government is very central and decisive. That is, if it is not taken then this case is similar with the government who does not have a 
good will to overcome hoax that leads to polarisation. It also becomes a discourse that arose in the discussion of the observational observer.

The expert staff of Kominfo Prof. Dr. Drs. Henri Subiakto, SH. M.Si said that a polarisation can not be easily handled, but it does not mean that the government does not have any dialogue with opposing groups. President Jokowi through his ministers and staff always communicates to break this polarisation. The problem is that Jokowi is so synonymous with PDI-P, whereas after becoming president, he belongs to all the people. As a consequence, the hoax that flourished and targeted the PDI-P (eg. about the PKI) also led to Jokowi. The second problem, at the distribution of hoax, everyone feels the most correct and true when the issues comes to circulation according to their interests, so to be a priori with the opposite group. For the counter group, the government is always considered to be objective. As the result, it creates an echo chamber (space echo) formation. According to Aristides Gionis of the Department of Computer Science Aalto University, echo chamber is a situation in which information, ideas or beliefs are amplified or reinforced by communication and repetition inside a defines system [15].

According to Henry, several things that the government has done is to establish communication with the community, social media activists (including Jonru Ginting) and interfaith leaders. Kominfo as part of the government has invited various parties to meet and dialogue, including a joint digital literacy campaign.

While Jokowi as the most frequently targeted entity of hoax, the effort handling this problem is not as easy as Kominfo. This case is because the ties of communication made a political dimension. The government actively invites the central and local MUI to take a part in handling the issues of hoax. Nevertheless admittedly, there are some parties who have not been invited to sit together and build an intense communication to overcome hoax.

The results of this research are very appealing to be studied through the theory of cognitive dissonance. This theory states that people have a tendency to be in psychological comfort and instead avoid psychological discomfort. In relation with hoax particularly and other information generally in social media, the first supporters of one group will try to avoid positive information from the other group or negative information from the group. Positive information about the opposite group or negative information about the group itself will put people in a dissonant condition that causes discomfort.

If it has been exposed an information that is contrary to the cognition (cognitive dissonance), then they will do four things: first, the behavior of adding consonant cognition, for example, it is is done by finding out that there are so many advantages possessed by the group. Second, it reduces cognition dissonance by adding information that the opposing groups do a lot of errors such as corruption. Third, it increases the importance of consonant cognition, for example by seeking justification "by allowing my group, so there are a lot of things that can be done for the progress of this country". Fourth, it reduces the importance of dissonant cognition, for example, the opposing group is too talkative with no evidence or too much imaging.

This theory is interesting to apply in such broad context in a country. Social media actually creates a paradox: in this medium, the flow of communication can go both ways, but it does not bring the atmosphere of dialogue. People only put forward their own opinions and ignore different opinions. If that is continuously actualized, then there will be a polarisation policing of public opinion, including political opinion.

Interestingly, in order to stay in a comfortable psychological state, in social media, the activists (pro and contra) and internet users will also follow accounts that are in line with their political views and unfollow opposite accounts. Thus, the confidence in his political group will be stronger because it is nurtured with the same information with his views. 
This case is reinforced by the workings of the Internet that works with certain algorithmic formula that produces a buble filter. Buble filters are often described as the potential for online personalization to effectively isolate people from a diversity or viewpoints or content [6]. The feeds on social media or search engines will only present anything that ever and is often searched by internet users. No wonder if, until now each group of pro and contra only speak in their respective space. This situation is often called the echo chamber.

\section{Conclusion}

From the results of the research above, there are two main conclusions that are set out, namely as follows;

1. Each party both from the pro and contra - group of government have a very high judgment on the phenomenon of hoax in relation with the government. This case makes difficulty to build a constructive discussion space because each one is only in the space and community that corresponds to its view (eco chamber).

2. The government has done various things ranging from the nature of prevention to the prosecution, but so far there has been no maximum results. At the prevention level, the government is considered to involve only pro-parties. While at the level of prosecution, the government in the case of police is often called a selective favoritism. This further strengthens the polarisation between the two parties.

3. The opinion that governement is partial or selective favoritism cannot be ignored. Therefore, it is necessary to create a discussion space on both sides, for example by inviting social media actors or buzzers from both sides. The discussions in the live meeting can reduce the 'cold war' on social media. The cases containing legal elements should also be processed, even if it is carried out by a pro-government party. Thus, a public trust to the government can be rebuilt.

\section{References}

[1] H. B. Dunn, S. F. Austin, and A. C. Allen, "Rumors, Urban Legends and Internet Hoaxes," in Proceedings of the Annual Meeting of the Association of Collegiate Marketing Educators, 2005, pp. 85-91.

[2] D. Maharani and D. R. Aritonan, "No Title," nasional.kompas.com, 2014. [Online]. Available:

https://nasional.kompas.com/read/2014/07/22/20574751/Ini.Hasil.Resmi.Rekapitulasi. Suara.Pilpres.2014.

[3] C. Franciska, "No Title," $B B C$, 2017. [Online]. Available: http://www.bbc.com/indonesia/trensosial-39618703.

[4] J. Ramdhani, "No Title," Detik, 2017. .

[5] I. Safutra, "No Title," Jawa Pos, 2017. [Online]. Available: https://www.jawapos.com/nasional/pemilihan/18/04/2017/1900-isu-hoax-munculjelang-pencoblosan-pilkada-dki-jakarta.

[6] T. T. Nguyen, P.-M. Hui, F. M. Harper, L. Terveen, and J. A. Konstan, "Exploring the Filter Bubble: The Effect of Using Recommender System on Content Diversity," in Proceeedings of The International World Wide Web Conference Committee (IW3C2), 
2014, pp. 677-686.

[7] B. K. Arrazy, "No Title," TEMPO.CO, 2017. [Online]. Available: https://nasional.tempo.co/read/901522/staf-kepresidenan-sebut-3-isu-hoax-yang-seringmenyerang-jokowi.

[8] E. Griffin, a First Look At Communication Theory(Eight Edition ed.). New York: McGraw Hill, 2012.

[9] Irwanto, Focused Group Discussion (FGD): Sebuah Pengantar Praktis. Jakarta: Yayasan Pustaka Obor Indonesia, 2006.

[10] B. Wiwoho, "No Title," CNN Indonesia, 2018. [Online]. Available: https://www.cnnindonesia.com/nasional/20180209215817-12-275206/polisi-sebutpemerintah-korban-hoax-terbanyak-di-media-sosial.

[11] A. Daud, "No Title," Katadata.co.id., 2016. [Online]. Available: https://katadata.co.id/berita/2016/12/29/jokowi-perintahkan-tindak-tegas-penyebarhoax.

[12] R. Jordan, "No Title," detikinet, 2017. [Online]. Available: https://inet.detik.com/cyberlife/d-3539993/jokowi-ajak-50-seleb-medsos-ke-istana.

[13] F. J. Kuwado, "No Title," Nasional Kompas, 2017. [Online]. Available: https://nasional.kompas.com/read/2017/08/24/19201111/bertemu-pegiat-media-sosialjokowi-paparkan-pencapaian-selama-3-tahun.

[14] U. D. Kusumawati, "No Title," CNN Indonesia, 2016. [Online]. Available: https://www.cnnindonesia.com/nasional/20160202164012-20-108395/jokowi-undang30-selebriti-medsos-ke-istana.

[15] A. Gionis, "Political Echo Chamber in Social Media," in NIPS Workshop, 2017. 